\title{
PENGARUH PENGGUNAAN VARIASI METODE DAN MODEL PEMBELAJARAN TERHADAP HASIL BELAJAR FISIKA SISWA KELAS VIII SMPN2 MARGATIGA SEMESTER GENAP TP 2013/2014
}

\author{
Eni Fitriani \\ H.R.A. Mulyani \\ Pendidikan Fisika FKIP Universitas Muhammadiyah Metro \\ Email: Hramulyani@gmail.com
}

\begin{abstract}
The purpose of this study was to investigate the effect of variations in the methods and models of teaching to student learning outcomes VIII SMPN2 MARGA TIGA.This research is experimental research which ofdesign completely randomized or completely randomized experimental design.The population in thisresearch is all of student VIII class in SMPN 2 MARGA TIGA2013/2014. The sample in this research is VIII $^{\text {th }}$ class which totaling 34 students.In this research, conducted with three treatments of learning in a classroom.Data collection techniques in this research use the technique of the test, which tests the end (posttest) were then analyzed with the test results hipotesis. From posttest analysis results of hypothesis testing using one-way ANOVA test (Completely Randomized Design) at the 5\% significance level value obtained results Fobs $=1.5244$ and Ftab $=$ 3.10 this shows that $H_{0}$ is accepted and means variety of methods and learning models provide a similar impact on student learning outcomes.It can be concluded that all three treatments had similar quality if tailored to the needs of all three materials.
\end{abstract}

\section{Keywords: Tandur Models, Methods Lectures and Learning Outcomes.}

\section{PENDAHULUAN}

Pembelajaran sains di sekolah dimaksudkan untuk menanamkan keyakinan kepada Allah SWT, mengembangkan keterampilan dan sikap ilmiah siswa, mempersiapkan siswa melek sains dan teknologi untuk pengembangan kemampuan siswa ke jenjang yang lebih tinggi. Oleh karena itu pembelajaran sains yang diperlukan adalah pembelajaran yang melibatkan peran aktif siswa. Untuk itu, guru sebaiknya merancang pembelajaran sains yang dapat meningkatkan dan merubah awal pengetahuan siswa terutama yang berkaitan dalam kehidupan sehari-hari .

Sejatinya awal pembelajaran yang berkesan akan membawa siswa untuk dapat merangsang rasa 
Eni. F., HRA Mulyani- Pengembangan Modul Pembelajaran ...

keingintahuan mengenai materi-materi yang akan dipelajari selanjutnya. Pelajaran fisika merupakan salah satu pelajaran yang rumit bagi sebagian siswa di sekolah. Terlebih dalam setiap pertemuan guru menyajikan materi untuk semua topik menggunakan model konvensional dengan metode ceramah saja, tanpa memvariasikan metode atau model lain yang menyebabkan hasil belajar rendah. Padahal di dalam silabus sudah terlihat jelas metode dan model pembelajaran bervariasi pada setiap topik pembelajaran. Jika metode dan model pembelajaran diterapkan sesuai dengan peruntukan dan kebutuhan tentu harapannya hasil belajar menjadi bermakna dan berhasil.

Semisal pada materi awal mayoritas terdapat definisi-definisi yang sesuai jika disampaikan dengan menggunakan metode ceramah. Metode ceramah akan terlihat keberhasilannya apabila digunakan dalam materi yang sesuai. Kemudian jika materi tersebut perlu adanya pembuktian maka disampaikan dengan menggunakan model pembelajaran yang menggunakan pembuktian, yang salah satunya adalah model pembelajaran TANDUR. Di dalam model pembelajaran TANDUR terdapat suatu proses dimana siswa Menumbuhkan, Mengalami, Menamai, Mendemonstrasikan, Mengulangi, dan Merayakan bersama-sama dengan guru atas keberhasilan yang diperoleh siswa atau kelompok belajar. Peneliti menggunakan model pembelajaran TANDUR karena model ini sesuai dengan kebutuhan materi yang akan digunakan dalam penelitian. Dengan memaksimalkan semua model dan metode pembelajaran yang digunakan dalam penyampaian materi pada setiap pertemuan, maka harapan peneliti tidak ada model pembelajaran yang dikatakan buruk seperti yang terjadi saat ini dilapangan. Metode ceramah seringkali dianggap sebagai metode pembelajaran yang menyebabkan ketidakberhasilan dalam belajar karena siswa jenuh dan kurang aktif.

Sebenarnya hal itu terjadi bukan karena metode ceramah itu buruk, tetapi karena gurukurang tepat untuk penyesuaian model tersebut dan kurang memperhatikan materi tertentu apakah sudah sesuai jika hanya menggunakan metode ceramah saja ataukah perlu adanya variasi dengan 
Eni. F., HRA Mulyani- Pengembangan Modul Pembelajaran...

menggunakan model pembelajaran lain kebutuhan materi sehingga dapat yang memenuhi kebutuhan materi. meningkatkan minat dan rasa ingin Dalam dunia pendidikan, telah kita tahu tentang materi yang akan ketahui bahwa tidak ada model dipelajari. Dan model yang akan pembelajaran terbaik, yang ada semua digunakan dalam penelitian adalah model pembelajaran baik apabila penggunaan metode ceramah, model penggunaannya disesuaikan dengan pembelajaran TANDUR disertai kebutuhan materi. Seperti menurut metode ceramah, dan model Sudjana (2000:77) ceramah adalah pembelajaran TANDUR. Model penuturan bahan pelajaran secara lisan. pembelajaran TANDUR yaitu kata Metode ini tidak akan baik apabila singkat dari Tumbuhkan, Alami, penggunaannya dipersiapkan dengan Namai, Demonstrasikan, Ulangi, baik, didukung dengan alat dan media, Rayakan. Model pembelajaran serta memperhatikan batas-batas TANDUR merupakan kerangka penggunaannya. Cara ini terkadang rancangan pembelajaran Quantum membosankan, maka dalam pe- Teaching. Kunci dari model laksanaannya memerlukan ketrampilan pembelajaran ini adalah membangun tertentu, agar penyajiannya tidak tingkat emosional terlebih dahulu untuk membosankan dan dapat menarik menciptakan kesenangan dalam belajar, perhatian siswa. Namun kita masih menjalin hubungan yang baik, mengakui bahwa metode ceramah ini menumbuhkan minat dan rasa ingin tetap penting dengan tujuan agar siswa tahu, menyingkirkan segala hambatan mendapatkan informasi tentang suatu baru, menyajikan konsep didalamnya pokok atau persoalan tertentu.

Pembelajaran yang dikemas dan diakhiri dengan penguatan dan motivasi agar konsep yang sudah menarik dan baik tentu saja akan dipelajari lekat dalam pikiran siswa.

berdampak positif untuk meningkatkan

Menurut DePoter dalam potensi belajar siswa. Salah satu jalan Hendiyani (2010) model pembelajaran keluar untuk meningkatkan hasil TANDUR adalah penerapan dari belajar, guru harus menggunakan Quantum Teaching yang cocok untuk metode atau tehnik yang sesuai dengan mata pelajaran apapun, dan apapun 
Eni. F., HRA Mulyani- Pengembangan Modul Pembelajaran...

tingkat kelasnya dan model ini menjamin siswa menjadi tertarik dan berminat dalam setiap pelajaran. Dengan membuat siswa menyukai pelajaran akan mempermudah proses pembelajaran karena siswa tidak merasa dipaksa dalam belajar.

Deporter (2005) menyatakan

bahwa Quantum Teaching juga memiliki asas utama yaitu "Bawalah Dunia Mereka Ke Dunia Kita, dan Antarkan Dunia Kita Ke Dunia Mereka". Dengan maksud mengingat pentingnya memasuki dunia murid sebagai langkah pertama.Untuk mendapatkan hak mengajar, pertama tama kita harus membangun jembatan untuk memasuki dunia murid.

\section{Model pembelajaran TANDUR}

telah digunakan oleh peneliti sebelumnya. Hendiyani (2010) yang menyatakan bahwa model pembelajaran TANDUR telah dilaksanakan dengan baik dalam pembelajaran di kelas. Sehingga hasil belajar dapat meningkat secara signifikan.
Berdasarkan uraian tersebut, rumusan masalah dalam penelitian ini adalah "apakah ada pengaruh yang sama penggunaan variasi metode dan model pembelajaran pada materi tekanan terhadap hasil belajar siswa kelas VIII SMPN2 MARGA TIGA?".

\section{METODE}

Penelitian ini dilaksanakan dikelas VIII $_{3}$ SMPN 2 MARGA TIGA pada semester genap tahun pelajaran 2013/2014. Waktu penelitian ini dilaksanakan pada 17 april sampai 30 april 2014. Jenis penelitian yang akan digunakan dalam penelitian ini adalah penelitian eksperimen dengan menggunakan desain rancangan acak lengkap atau completely randomized design. Rancangan acak lengkap merupakan salah satu model rancangan dalam rancangan percobaan. Rancangan acak lengkap digunakan bila unit percobaan homogen. Dalam penelitian ini, peneliti menggunakan satu kelas dengan tiga perlakuan menggunakan model yang sesuai dengan materi. Pertemuan pertama peneliti akan menggunakan metode ceramah, karena pada materi pertemuan pertama metode ceramah 
Eni. F., HRA Mulyani- Pengembangan Modul Pembelajaran...

sesuai dengan kebutuhan materi. 71,4706, dan pertemuan ketiga Pertemuan kedua, peneliti 72,9142.

penggunakan model pembelajaran Berdasarkan hasil uji normalitas TANDUR disertai metode ceramah. Sedangkan pertemuan ketiga peneliti menggunakan model pembelajaran TANDUR karena model ini sesuai dengan materi yang akan disampaikan.

Intrumen penelitian ini adalah berupa lembar observasi dan tes hasil belajar kognitif. Selanjutnya teknik pengumpulan data yaitu dengan memberikan tes hasil belajar. Pemberian tes hasil belajar ini dilakukan setelah pembelajaran. Teknik analisis data dalam penelitian ini dilakukan dengan analisis statistik uji normalitas, uji homogenitas dan uji hipotesis statistik anava satu arah (Rancangan Acak Lengkap).

\section{HASIL DAN PEMBAHASAN}

Hasil penelitian belajar kognitif pada kelas $\mathrm{VIII}_{3}$ materi tekanan yang diberikan tiga perlakuan yang berbeda pada setiap pertemuan dengan menggunakan variasi metode dan model pembelajaran memberikan ratarata hasil belajar pada pertemuan pertama 66,7647, pertemuan kedua untuk data hasil belajar pertemuan pada taraf signifikansi 0,05 menunjukkan $L_{0.05,34} 0,1519 ; \quad D K\{L \mid L>$ $0,1519\}$ dan $L_{o b s}=0,1243 \notin D K$ maka $H_{0}$ diterima artinya sampel berasal dari populasi yang berdistribusi normal. Data hasil belajar pertemuan kedua $\quad L_{0.05,34}=0,1519 ; D K=$ $\{L \mid L>01519$,$\} dan L_{o b s}=0,1323 \notin$ $D K$ maka $H_{0}$ diterima artinya sampel berasal dari populasi yang berdistribusi normal. Data hasil belajar pertemuan ketiga $\quad L_{0.05,31}=0,1591 ; D K=$ $\{L \mid L>0,1591\}$ dan $L_{o b s}=0,1382 \notin$ $D K$ maka $H_{0}$ diterima artinya sampel berasal dari populasi yang berdistribusi normal.Untuk uji homogenitas pada tingkat signifikansi 0,05 menunjukkan bahwa $\chi_{0,05 ; 2}^{2}=5,991 ;$ dan $D K=$ $\left\{\chi^{2} \mid \chi^{2}>5,991\right\} ; \chi_{o b s}^{2}=0,2232 \notin$ $D K$ maka $\mathrm{H}_{0}$ diterima artinya variansivariansi dari tiga populasi tersebut sama (homogen). Dan untuk uji hipotesis anava satu arah (Rancangan Acak Lengkap) dengan taraf signifikansi 0,05 menunjukkan bahwa $F_{0.05,2,99}=3,10 ; D K=\{F \mid F>3,10\}$ 
dan $F_{o b s}=1,5244 \notin D K$. Hal ini dengan kebutuhan materi dan menunjukkan bahwa $\mathrm{H}_{0}$ diterima dan disampaikan secara maksimal.

artinya variasi metode dan model pembelajaran memberikan dampak yang sama terhadap hasil belajar siswa.

(Budiyono, 2009)

Berdasarkan hasil yang

diperoleh dari penelitian di SMPN 2 Marga Tiga dan hasil analisis data dengan anava satu jalan (Rancangan Acak Lengkap), terlihat bahwa penggunaan variasi metode dan model pembelajaran memberikan dampak yang sama terhadap hasil belajar siswa. Hal ini ditandai dengan hasil posttest yang telah dilakukan pada tiga pertemuan yang menggunakan variasi metode dan model pembelajaran dengan penyesuaian terhadap kebutuhan materi. Meskipun ada perbedaan rata-rata hasil belajar antara perlakuan pertama, perlakuan kedua, dan perlakuan ketiga namun setelah dianalisis statistik dengan menggunakan uji anava satu arah (Rancangan Acak Lengkap) ketiga perlakuan yang diberikan memiliki kualitas yang sama untuk memberikan hasil belajar yang baik karena ketiga perlakuan yang digunakan sudah sesuai
Penggunaan variasi metode dan model pembelajaran yang dikemas dalam sebuah pembelajaran yang menarik dan menyenangkan, dilakukan dengan cara menyesuaikan metode dan model pembelajaran dengan materi dan memaksimalkan penggunaan masingmasing metode dan model pembelajaran.

Dari ketiga pertemuan yang menggunakan masing-masing metode dan model pembelajaran yang telah disesuaikan dengan peruntukan materi tersebut, ternyata memiliki dampak yang sama terhadap hasil belajar siswa. Guru juga telah memaksimalkan metode dan model yang digunakan dalam penelitian sehingga materi dapat diterima siswa dengan baik yang mengakibatkan hasil belajar siswa ratarata dalam setiap pertemuan adalah baik.

Menurut hasil pengamatan peneliti pada saat berlangsungnya penelitian siswa yang dapat memenuhi kriteria belum tuntas karena pada saat pembelajaran beberapa siswa tersebut kurang mengikuti pembelajaran dengan baik. Secara umum hal ini disebakan 
Eni. F., HRA Mulyani- Pengembangan Modul Pembelajaran...

oleh beberapa kendala diantaranya terdapat sebagian siswa yang masih mengobrol dan sibuk dengan teman sebangkunya pada saat guru menjelaskan materi, atau tidak aktif pada saat melakukan percobaan sehingga mengakibatkan siswa kurang memahami materi. Siswa tidak menyampaikan pendapat mereka dan tidak mengerjakan soal latihan yang dibarikan oleh guru dengan alasan tidak mengerti, siswa hanya berpikir sebatas yang diketahui saja.

Penggunaan metode ceramah, model TANDUR disertai ceramah, dan model TANDUR memberikan hasil yang sama baik. Dalam penggunaan ketiga perlakuan tersebut yang disesuaikan dengan kebutuhan materi terlihat hasil belajar yang sama-sama berpengaruh baik dimana lebih banyak siswa yang tuntas dibandingkan siswa yang belum tuntas. Hal ini dikarenakan pada setiap pembelajaran dengan perlakuan yang berbeda siswa mampu berperan aktif, mengalami langsung materi dan merasa bahwa diri masingmasing siswa memiliki kemampuan untuk disampaikan pada saat pembelajaran.
Secara umum semua model dan metode pembelajaran akan mendapatkan hasil belajar yang baik apabila penyampaiannya sudah sesuai dengan langkah-langkah yang ada pada setiap model pembelajaran dan memaksimalkan kinerjanya sehingga tidak ada model atau metode yang dianggap kurang memaksimalkan hasil belajar. Dalam silabus, setiap konsep materi pelajaran memiliki metode dan model serta pendekatan yang bervariasi pada saat kita menyampaikannya. Artinya dalam satu konsep materi yang terdiri dari beberapa sub konsep yang dilaksanakan dalam beberapa kali pertemuan ternyata metode dan model pembelajaran juga harus bervariasi setiap kali pertemuan agar siswa tidak jenuh dan memahami materi pembelajaran sehingga dapat memberikan hasil belajar yang lebih baik.

\section{PENUTUP}

\section{Kesimpulan}

Kesimpulan yang diperoleh dari penelitian yang dilakukan mengenai "pengaruh penggunaan variasi metode dan model pembelajaran terhadap hasil belajar fisika siswa kelas 
Eni. F., HRA Mulyani- Pengembangan Modul Pembelajaran...

VIII SMPN 2 Marga Tiga semeter genap Tahun Pelajaran 2013/2014” adalah:

- Variasi metode dan model pembelajaran yang digunakan pada satu konsep materi pelajaran memiliki pengaruh yang sama. Meskipun rerata untuk pembelajaran yang menggunakan model pembelajaran TANDUR lebih tinggi dari rerata pembelajaran yang menggunakan metode ceramah atau model pembelajaran TANDUR disertai metode ceramah.

- Aktivitas siswa selama proses pembelajaran dengan metode dan model pembelajaran setiap pertemuan cukup aktif dan sebagian besar siswa mau berpartisipasi dalam proses pembelajaran karena guru memaksimalkan metode dan model pembelajaran yang digunakan.

\section{Saran}

Terdapat beberapa saran yang dapat peneliti berikan yang terkait dalam penelitian ini, diantaranya:

- Bagi sekolah khususnya bagi guru, hendaknya menggunakan variasi metode dan model pembelajaran dalam proses pembelajaran, menyesuaikan metode dan model pembelajaran dengan kebutuhan materi sehingga materi dapat lebih mudah diterima oleh siswa dan siswa tidak merasa bosan sehingga siswa dapat lebih aktif serta kreatif.

- Guru harus mengupayakan agar siswa mampu mengkomunikasikan ide alamiah yang sudah mereka miliki, menghargai bahasa seharihari siswa dan meminta siswa untuk mengungkapkan fisika yang mereka pelajari dalam bahasa sehari-hari mereka agar siswa lebih mudah memahami materi yang telah mereka pelajari.

- Bagi siswa hendaknya selalu berusaha untuk memahami sendiri materi yang disampaikan, memanfaatkan kelompok belajar dengan sebaikbaiknya dan senantiasa melakukan evaluasi untuk mengukur tingkat keberhasilan yang telah dicapai.

\section{DAFTAR PUSTAKA}

Budiyono. 2009. Statistika Untuk Penelitian.Surakarta:UNS Press 
Eni. F., HRA Mulyani- Pengembangan Modul Pembelajaran...

Deporter, Bobbi dkk.2005. Quantum

Teaching.Bandung:Kaifa

Hendiyani, Iin.2010. Pengaruh Model

Pembelajaran TANDUR

Terhadap Hasil Belajar Fisika

Siswa. Jakarta: UIN Syarif

Hidayatullah

Sudjana, Nana. 2000. Dasar-Dasar

Proses Belajar Mengajar.

Bandung: Sinar Baru

Algesindo. 